\title{
Effects of sodium chloride on the gene expression profile of periodontal ligament fibroblasts during tensile strain
}

\author{
Agnes Schröder ${ }^{1}$ Joshua Gubernator ${ }^{1}$ Ute Nazet ${ }^{1}$ Gerrit Spanier ${ }^{2}$ Jonathan Jantsch ${ }^{3} \cdot$ Peter Proff $^{1}$. \\ Christian Kirschneck ${ }^{1}$
}

Received: 16 December 2019 / Accepted: 31 March 2020 / Published online: 6 July 2020

(c) The Author(s) 2020, corrected publication 2021

\begin{abstract}
Purpose During orthodontic tooth movement, pressure and tension zones develop in the periodontal ligament, and periodontal ligament fibroblasts (PDLF) become exposed to mechanical strain. Enhanced salt ( $\mathrm{NaCl}$ ) concentrations are known to modulate responses of PDLF and immune cells to different stimuli like mechanical strain. Here, we investigated the impact of tensile strain on the gene expression profile of PDLF under normal (NS) and high salt (HS) conditions.

Methods After preincubation under NS or $\mathrm{HS}(+40 \mathrm{mM} \mathrm{NaCl}$ in medium) conditions for $24 \mathrm{~h}$, PDLF were stretched $16 \%$ for $48 \mathrm{~h}$ using custom-made spherical cap silicone stamps using an established and published setup. After determination of cell number and cytotoxicity, we analyzed expression of genes involved in extracellular matrix reorganization, angiogenesis, bone remodeling, and inflammation by quantitative real-time polymerase chain reaction (RT-qPCR).

Results Tensile strain did not affect the expression of genes involved in angiogenesis or extracellular matrix reorganization by PDLF, which however modulate inflammatory responses and bone remodeling in reaction to $16 \%$ static tensile strain. Salt $(\mathrm{NaCl})$ treatment triggered enhanced extracellular matrix formation, expression of cyclooxygenase 2 and bone metabolism in PDLF during tensile strain.

Conclusions Salt $(\mathrm{NaCl})$ consumption may influence orthodontic tooth movement and periodontal bone loss via modulation of extracellular matrix and bone metabolism. Excessive salt intake during orthodontic therapy may cause adverse effects regarding periodontal inflammation and bone resorption.
\end{abstract}

Keywords Periodontal ligament fibroblast · Periodontal ligament (PDL) · Orthodontic tooth movement · Tensile strain · Expression kinetics

PD Dr. rer. nat. Agnes Schröder

agnes.schroeder@ukr.de

Joshua Gubernator

joshua.gubernator@stud.uni-regensburg.de

PD Dr. Dr. (PhD) Christian Kirschneck, DDS

Ute Nazet

ute.nazet@ukr.de

Dr. Gerrit Spanier, MD, DDS

gerrit.spanier@ukr.de

Jonathan Jantsch

jonathan.jantsch@ukr.de

Professor Dr. Dr. (PhD) Peter Proff, MD, DDS

peter.proff@ukr.de

christian.kirschneck@ukr.de

1 Department of Orthodontics, University Hospital Regensburg, Franz-Josef-Strauß-Allee 11, 93053 Regensburg, Germany

2 Department of Cranio-Maxillo-Facial Surgery, University Hospital Regensburg, Franz-Josef-Strauß-Allee 11, 93053 Regensburg, Germany

3 Institute of Clinical Microbiology and Hygiene, University Hospital Regensburg, Franz-Josef-Strauß-Allee 11, 93053 Regensburg, Germany 


\section{Auswirkungen von Natriumchlorid auf das Genexpressionsprofil parodontaler Ligamentfibroblasten bei Dehnung}

\section{Zusammenfassung}

Ziel Während der kieferorthopädischen Zahnbewegung entwickeln sich Druck- und Zugzonen im Parodontalligament, und parodontale Ligamentfibroblasten (PDLF) werden mechanischer Belastung ausgesetzt. Es ist bekannt, dass erhöhte Salzkonzentrationen $(\mathrm{NaCl})$ die Reaktionen von PDLF und Immunzellen auf verschiedene Stimuli wie mechanische Beanspruchung modulieren. Hier untersuchten wir den Einfluss von Dehnung auf das Genexpressionsprofil von PDLF unter Normal- (NS) und unter Hochsalzbedingungen (HS).

Methoden Nach $24 \mathrm{~h}$ Vorinkubation unter NS- bzw. HS-Bedingungen ( $+40 \mathrm{mM} \mathrm{NaCl}$ im Medium) wurden PDLF $48 \mathrm{~h}$ lang unter Verwendung von Silikonstempeln unter Verwendung eines etablierten und veröffentlichten Protokolls um 16\% gestreckt. Nach Bestimmung der Zellzahl und der Zytotoxizität analysierten wir durch RT-qPCR (,,quantitative real-time polymerase chain reaction") die Expression von Genen, die an der Reorganisation der extrazellulären Matrix, der Angiogenese, dem Knochenumbau und der Entzündung beteiligt sind.

Ergebnisse Dehnung hatte keinen Einfluss auf die Expression von Genen, die an der Angiogenese oder der Reorganisation der extrazellulären Matrix durch PDLF beteiligt sind. In Reaktion auf statische Dehnung modulierten PDLF jedoch die Expression von Genen, die an Entzündungsreaktionen und am Knochenumbau beteiligt sind. Eine Behandlung mit Salz $(\mathrm{NaCl})$ bewirkte während der Zugbelastung eine vermehrte Bildung von extrazellulärer Matrix sowie eine verstärkte Expression von Cyclooxygenase 2 und von Markern des Knochenmetabolismus durch PDLF.

Schlussfolgerungen Salzkonsum kann die kieferorthopädische Zahnbewegung und den parodontalen Knochenverlust durch Modulation der extrazellulären Matrix und des Knochenstoffwechsels beeinflussen. Eine übermäßige Salzaufnahme während der kieferorthopädischen Therapie könnte daher nachteilige Auswirkungen auf parodontale Entzündungen und die Knochenresorption haben.

Schlüsselwörter Parodontalligament (PDL) · Parodontalligament-Fibroblasten · Kieferorthopädische Zahnbewegung · Dehnung · Genexpression

\section{Introduction}

During orthodontic tooth movement, pressure and tension zones develop in the periodontal ligament (PDL), a connective tissue responsible for the attachment of the tooth to the alveolar bone [25]. Periodontal ligament fibroblasts (PDLF) make up the majority of cells within the periodontal ligament and are the first cells exposed to mechanical stimuli occurring during orthodontic tooth movement. The main function of PDLF is the maintenance of tissue homeostasis and production of collagenous structural proteins and glycosaminoglycans. Furthermore, they sustain regulatory functions in innate immune defense [16, 25].

After an orthodontic force is applied to the tooth, PDLF are subjected to mechanical strain and play an important regulatory role in orthodontic tooth movement. As an early response to compressive forces, PDLF increase prostaglandin production via enhancement of cyclooxygenase $2(\mathrm{COX}-2)$ activity, resulting in enhanced expression of RANKL (receptor activator of NF- $\kappa B$ ligand) $[16,38$, 48], while simultaneously secretion of RANKL decoy receptor osteoprotegerin (OPG) is reduced [38]. This promotes osteoclastogenesis in pressure areas of the PDL resulting in alveolar bone resorption. In contrast, in tension areas bone formation by osteoblastic activity is promoted [25].

Malocclusions have a negative impact on oral-health-related quality of life and mental well-being of children leading to reduced self-confidence $[8,42]$. Often these psychological effects triggered by malocclusions are the reason to improve esthetics through orthodontic treatment [42]. Therapy of malocclusions is of distinct medical importance, as recent studies associated malpositioned teeth with the development of caries or periodontitis [2, 37, 41]. Therefore, orthodontic corrections are helpful to prevent the development and progression of these oral diseases. Despite the importance of orthodontic treatment for oral health, many aspects of orthodontic therapy remain uninvestigated, and many problems that arise during an ongoing orthodontic therapy are still unresolved.

Possible influences of nutrition on orthodontic treatment have hardly been investigated. Since orthodontic tooth movement comprises a local sterile-inflammatory process, numerous possibilities exist for the immune system and general metabolism to modulate these processes $[18,53]$. Components of nutrition are reported to influence not only chronic diseases like hypertension [22, 23] or osteopenia [44], but also have an impact on the oral microflora [52] and periodontal bone loss [29]. In Western societies electrolytes 
such as sodium are consumed to a high degree as food supplements in the form of salt (sodium chloride, $\mathrm{NaCl}$ ) and are known to modulate tissue response to different stimuli by their local tissue concentration [28]. It can be assumed that about 70-80\% of the salt intake comes from "hidden" salts in processed foods such as cheese, bread, and readyto-eat meals [6]. Most people in Europe consume significantly more salt $(8-11 \mathrm{~g} /$ day) than recommended by the German Nutrition Society (1.5 g/day) [6, 51]. Therefore, it can be assumed that salt-related effects on orthodontic tooth movement in industrialized nations are relevant to the vast majority of patients.

Consumption of high salt diet or inflammation induces $\mathrm{Na}^{+}$accumulation in various tissues, thereby, modulating the activity of cells of the mononuclear phagocytic system [3, 14, 22, 23]. Furthermore, $\mathrm{Na}^{+}$accumulation may also occur in tissues of the oral cavity, especially the gingiva, the oral mucous membrane, and the periodontal ligament [39]. As salt (sodium chloride) is known to have a direct impact on the activity of cells of the mononuclear phagocytic system [14, 23, 32] and osteoclasts [54], it may also have an effect on the response of PDLF to tensile strain.

\section{Materials and methods}

\section{In vitro cell culture experiments}

All experiments were performed in accordance with the relevant guidelines and regulations. Approval for the collection and use of PDLF was obtained from the ethics committee of the University of Regensburg, Germany (approval number 12-170-0150). We obtained informed consent from all patients or their legal guardians.

Periodontal ligament fibroblasts (PDLF) were isolated from periodontal ligament tissue scraped off the middle third of human teeth. For these experiments we used a pool of PDLF from six different patients ( 3 male, 3 female, age range 17-27 years). Isolation and characterization was performed as previously described [17, 38]. For our experiments, we used PDLF of the 3rd to 6th passage. We determined cell number with a Beckman Coulter Counter Z2 ${ }^{\mathrm{TM}}$ (Beckman Coulter GmbH, Krefeld, Germany) according to the manufacturer's instructions.

A total of 70,000 PDLF in $2 \mathrm{ml}$ media (Dulbecco's Modified Eagle Medium [DMEM] high glucose, D5796, SigmaAldrich, Munich, Germany); 10\% FBS (fetal bovine serum, P30-3306, PAN-Biotech, Aidenbach, Germany), 1\% L-glutamine (SH30034.01, GE Healthcare Europe, Munich, Germany), $100 \mu \mathrm{M}$ ascorbic acid (A8960, Sigma-Aldrich, Munich, Germany), and $1 \%$ antibiotics/antimycotics (A5955, Sigma-Aldrich, Munich, Germany) were seeded onto 6-well collagen-I-coated bioflex plates (BF-3001C, Dunn Labortechnik, Asbach, Germany). After 24h preincubation time without (normal salt [NS] conditions) or with addition of $40 \mathrm{mM} \mathrm{NaCl}$ (high salt [HS] conditions, 1162241000 , Sigma-Aldrich, Munich, Germany), we performed $16 \%$ static isotropic cell stretching for an additional $48 \mathrm{~h}$ by using custom-made spherical cap silicone stamps (Fig. 1a) according to an established and published method [30] consisting of two-component silicone (43004,490068, Turbosil, Klasse 4, Dental GmbH, Augsburg, Germany; mixed 1:1 with Dosper evo, Dreve GmbH, Unna, Germany). In a previous study using the same setup, this tensile strain a

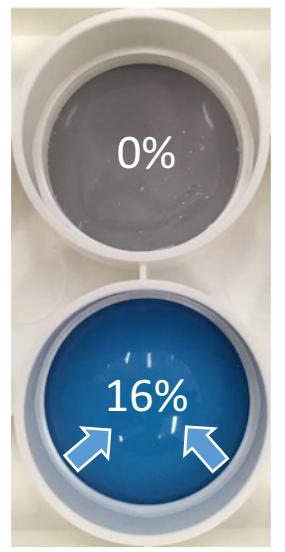

b

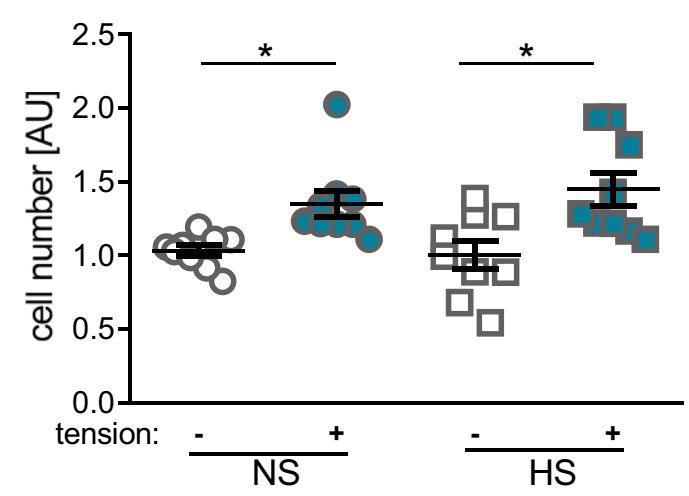

C

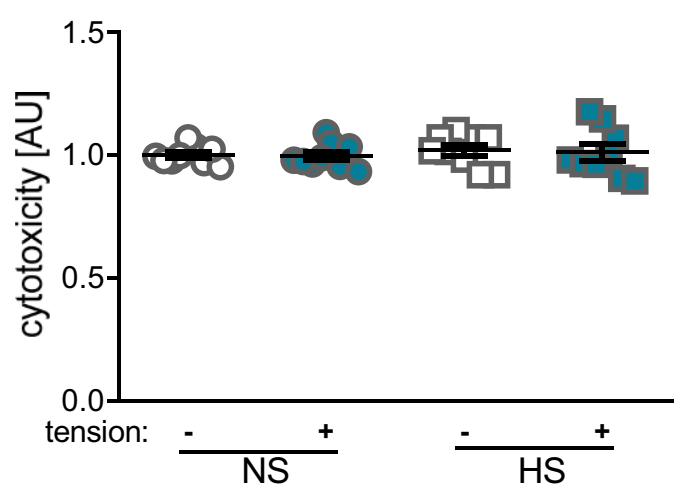

Fig. 1 a In vitro simulation of tensile strain by isotropic stretching of adherently growing periodontal ligament fibroblasts (PDLF). Determination of cell number (b) and cytotoxicity by LDH assay (c). NS normal salt conditions, HS high salt conditions, AU arbitrary units, error bars error of the mean. Statistics: Analysis of variance (ANOVA) using the Games-Howell post hoc test: ${ }^{*} p \leq 0.05$

Abb. 1 a In-vitro-Simulation der Zugspannung durch isotrope Dehnung von adhärent wachsenden PDLF (parodontale Ligamentfibroblasten). Bestimmung der Zellzahl (b) und der Zytotoxizität durch LDH(Laktatdehydrogenase)-Assay (c). (NS Normalsalz-, $H S$ Hochsalzbedingungen, $A U$ arbiträre Einheiten, Fehlerbalken Fehler des Mittelwerts. Statistik: ANOVA (,,analysis of variance“) mit Games-Howell-Post-hoc-Test: * $p \leq 0,05$ ) 
Table 1 RT-qPCR primer sequences for reference genes (TBP, PPIB) and target genes

Tab. 1 RT-qPCR-Primersequenzen der Referenzgene (TBP, PPIB) und der Zielgene

\begin{tabular}{|c|c|c|c|c|}
\hline $\begin{array}{l}\text { Gene } \\
\text { symbol }\end{array}$ & Gene name & $\begin{array}{l}\text { Accession Num- } \\
\text { ber } \\
\text { (NCBI Gen- } \\
\text { Bank) }\end{array}$ & $\begin{array}{l}5^{\prime} \text {-forward primer-3' } \\
\text { (length/Tm } / \% \mathrm{GC} / \max . \Delta \mathrm{G} \text { Hairpin } \\
\text { \&Self-Dimer/Self-Comp./Self-3'-Comp.) }\end{array}$ & $\begin{array}{l}5^{\prime} \text {-reverse primer-3' } \\
\text { (length/ } \mathrm{T}_{\mathrm{m}} / \% \mathrm{GC} / \mathrm{max} . \Delta \mathrm{G} \text { Hairpin } \\
\text { \&Self-Dimer/Self-Comp./Self-3'-Comp.) }\end{array}$ \\
\hline$T B P$ & $\begin{array}{l}\text { TATA box binding } \\
\text { protein }\end{array}$ & NM_003194.4 & $\begin{array}{l}\text { CGGCTGTTTAACTTCGCTTCC } \\
\left(21 \mathrm{bp} / 62.5^{\circ} \mathrm{C} / 52.4 \% /-0.8 / 5 / 0\right)\end{array}$ & $\begin{array}{l}\text { TGGGTTATCTTCACACGCCAAG } \\
\left(22 \mathrm{bp} / 63.4^{\circ} \mathrm{C} / 50.0 \% /-1.5 / 3 / 2\right)\end{array}$ \\
\hline$P P I B$ & $\begin{array}{l}\text { Peptidylprolyl } \\
\text { isomerase A }\end{array}$ & NM_000942.4 & $\begin{array}{l}\text { TTCCATCGTGTAATCAAGGACTTC } \\
\left(24 \mathrm{bp} / 61.3^{\circ} \mathrm{C} / 41.7 \% /-1.3 / 4 / 2\right)\end{array}$ & $\begin{array}{l}\text { GCTCACCGTAGATGCTCTTTC } \\
\left(21 \mathrm{bp} / 61.2^{\circ} \mathrm{C} / 52.4 \% /-0.7 / 4 / 0\right)\end{array}$ \\
\hline$A L P$ & $\begin{array}{l}\text { Alkaline phos- } \\
\text { phatase }\end{array}$ & NM_000478.4 & $\begin{array}{l}\text { ACAAGCACTCCCACTTCATCTG } \\
\left(22 \mathrm{bp} / 60.3{ }^{\circ} \mathrm{C} / 50.0 \% /-0.5 / 3 / 2\right)\end{array}$ & $\begin{array}{l}\text { GGTCCGTCACGTTGTTCCTG } \\
\left(20 \mathrm{bp} / 61.4^{\circ} \mathrm{C} / 60.0 \% /-3.3 / 5 / 1\right)\end{array}$ \\
\hline COL1A2 & $\begin{array}{l}\text { Collagen, type I, } \\
\text { alpha } 2\end{array}$ & NM_000089.3 & $\begin{array}{l}\text { AGAAACACGTCTGGCTAGGAG } \\
\left(21 \mathrm{bp} / 59.8^{\circ} \mathrm{C} / 52.4 \% /-3.3 / 4 / 2\right)\end{array}$ & $\begin{array}{l}\text { GCATGAAGGCAAGTTGGGTAG } \\
\left(21 \mathrm{bp} / 59.8^{\circ} \mathrm{C} / 52.4 \% /-2.3 / 5 / 0\right)\end{array}$ \\
\hline$C O X-2$ & Cyclooxygenase 2 & NM_000963.3 & $\begin{array}{l}\text { GAGCAGGCAGATGAAATACCAGTC } \\
\left(24 \mathrm{bp} / 62.7^{\circ} \mathrm{C} / 50.0 \% / 0.0 / 2 / 2\right)\end{array}$ & $\begin{array}{l}\text { TGTCACCATAGAGTGCTTCCAAC } \\
\left(23 \mathrm{bp} / 60.6^{\circ} \mathrm{C} / 47.8 \% /-1.3 / 4 / 0\right)\end{array}$ \\
\hline FN1 & Fibronectin 1 & NM_212482.1 & $\begin{array}{l}\text { GCCAGTCCTACAACCAGTATTCTC } \\
\left(24 \mathrm{bp} / 62.7^{\circ} \mathrm{C} / 50.0 \% /-0.3 / 4 / 2\right)\end{array}$ & $\begin{array}{l}\text { GCTTGTTCCTCTGGATTGGAAAG } \\
\left(23 \mathrm{bp} / 60.6^{\circ} \mathrm{C} / 47.8 \% /-2.5 / 4 / 1\right)\end{array}$ \\
\hline$I L-6$ & Interleukin 6 & NM_000600.3 & $\begin{array}{l}\text { TGGCAGAAAACAACCTGAACC } \\
\left(21 \mathrm{bp} / 57.9^{\circ} \mathrm{C} / 47.6 \% /-1.1 / 3 / 0\right)\end{array}$ & $\begin{array}{l}\text { CCTCAAACTCCAAAAGACCAGTG } \\
\left(23 \mathrm{bp} / 60.6^{\circ} \mathrm{C} / 47.8 \% /-0.8 / 3 / 3\right)\end{array}$ \\
\hline$M M P 8$ & $\begin{array}{l}\text { Matrix-metallo- } \\
\text { proteinase- } 8\end{array}$ & NM_002424.2 & $\begin{array}{l}\text { GCTCATTTTGATGCCGAAGAAAC } \\
\left(23 \mathrm{bp} / 58.9^{\circ} \mathrm{C} / 43.5 \% /-0.9 / 3 / 0\right)\end{array}$ & $\begin{array}{l}\text { CCCTGAAAGCATAGTTGGGATAC } \\
\left(23 \mathrm{bp} / 60.6^{\circ} \mathrm{C} / 47.8 \% /-2.0 / 3 / 2\right)\end{array}$ \\
\hline P4HAl & $\begin{array}{l}\text { Prolyl 4-hydroxy- } \\
\text { lase, } \alpha \text { I }\end{array}$ & NM_000917.3 & $\begin{array}{l}\text { GCTCTCTGGCTATGAAAATCCTG } \\
\left(23 \mathrm{bp} / 60.6^{\circ} \mathrm{C} / 47.8 \% / 0.0 / 2 / 2\right)\end{array}$ & $\begin{array}{l}\text { GTGCAAAGTCAAAATGGGGTTC } \\
\left(22 \mathrm{bp} / 58.4^{\circ} \mathrm{C} / 45.5 \% /-3.4 / 4 / 0\right)\end{array}$ \\
\hline$O P G$ & Osteoprotegerin & NM_002546.3 & $\begin{array}{l}\text { TGTCTTTGGTCTCCTGCTAACTC } \\
\left(23 \mathrm{bp} / 60.6{ }^{\circ} \mathrm{C} / 47.8 \% / 0.0 / 2 / 0\right)\end{array}$ & $\begin{array}{l}\text { CCTGAAGAATGCCTCCTCACAC } \\
\left(22 \mathrm{bp} / 62.1^{\circ} \mathrm{C} / 54.6 \% /-0.9 / 4 / 0\right)\end{array}$ \\
\hline$R A N K L$ & $\begin{array}{l}\text { Receptor activator } \\
\text { of NF- } \kappa B \text { ligand }\end{array}$ & NM_003701.3 & $\begin{array}{l}\text { ATACCCTGATGAAAGGAGGA } \\
\left(20 \mathrm{bp} / 54.9^{\circ} \mathrm{C} / 45.0 \% /-1.3 / 3 / 0\right)\end{array}$ & $\begin{array}{l}\text { GGGGCTCAATCTATATCTCG } \\
\left(20 \mathrm{bp} / 54.6^{\circ} \mathrm{C} / 50.0 \% /-0.5 / 4 / 2\right)\end{array}$ \\
\hline$V E G F A$ & $\begin{array}{l}\text { Vascular endothe- } \\
\text { lial growth fac- } \\
\text { tor A }\end{array}$ & NM_001171623.1 & $\begin{array}{l}\text { TGCAGACCAAAGAAAGATAGAGC } \\
\left(23 \mathrm{bp} / 58.9^{\circ} \mathrm{C} / 43.5 \% /-3.4 / 4 / 2\right)\end{array}$ & $\begin{array}{l}\text { ACGCTCCAGGACTTATACCG } \\
\left(20 \mathrm{bp} / 59.4^{\circ} \mathrm{C} / 55.0 \% /-1.3 / 5 / 2\right)\end{array}$ \\
\hline
\end{tabular}

$T_{m}$ melting temperature of primer/specific qPCR product (amplicon), \%GC guanine/cytosine content, Comp. Complementarity, $b p$ base pair

magnitude was shown to be the minimum magnitude to significantly affect the expression of proinflammatory genes in PDLF [30].

\section{Assessment of cell number}

After $48 \mathrm{~h}$ of isotropic tensile strain, the medium was removed and PDLF were scraped off the bioflex membrane in $1 \mathrm{ml}$ phosphate buffered saline (PBS) for cell number determination. Cells were counted automatically using a Beckman Coulter Counter Z2 ${ }^{\mathrm{TM}}$ (Beckman Coulter $\mathrm{GmbH}$, Krefeld, Germany) according to the manufacturer's instructions.

\section{LDH cytotoxicity assay}

To test for cytotoxicity, we performed lactate dehydrogenase (LDH) assays (04744926001, Roche, Mannheim, Germany) using cell culture supernatants according to the manufacturer's instructions. A total of $100 \mu 1$ of cell culture supernatant was mixed with $100 \mu \mathrm{l}$ freshly prepared LDH solution (consisting of $22 \mu \mathrm{l}$ catalyst in $1 \mathrm{ml}$ dye). After an incubation period of $30 \mathrm{~min}$ at room temperature in the dark, $50 \mu$ l stop solution was added and absorbance was measured at $490 \mathrm{~nm}$ using an ELISA reader (Multiscan GO Microplate Spectrophotometer, Thermo Fisher Scientific, Waltham, MA, USA), subtracting background absorbance at $690 \mathrm{~nm}$.

\section{RNA isolation and CDNA synthesis}

RNA isolation was performed as previously described according to MIQE (Minimum Information for Publication of Quantitative Real-Time PCR Experiments) guidelines $[17,30]$. A total of $500 \mu \mathrm{l}$ peqGOLD TriFast ${ }^{\mathrm{TM}}$ (PEQLAB Biotechnology $\mathrm{GmbH}$, Erlangen, Germany) was added per well and further processed according to the manufacturer's instructions. The resulting RNA pellet was resuspended in $20 \mu \mathrm{l}$ nuclease-free doubly distilled water $\left(\mathrm{H}_{2} \mathrm{O}_{\mathrm{dd}}\right.$; T143, Carl Roth, Karlsruhe, Germany). RNA was quantified using a NanoPhotometer (N60; Implen, Munich, Germany). A total of 100 ng RNA per sample was transcribed into cDNA using $1 \mu$ oligo-dT18 primer (SO131, Thermo Fisher Scientific Inc., Waltham, MA, USA), $1 \mu$ random hexamer primer (SO142, Thermo Fisher Scientific Inc.), $1 \mu \mathrm{l}$ dNTP mix (L785.2, Roti ${ }^{\circledR}$-Mix PCR3, Carl Roth), $1 \mu$ RNase inhibitor 
(EO0381, Thermo Fisher Scientific Inc.), $1 \mu \mathrm{l}$ MLV-reverse transcriptase (M1705, Promega, Fitchburg, WI, USA), $4 \mu \mathrm{l}$ $5 \times$ M-MLV-buffer (M1705, Promega) in a total volume of $20 \mu \mathrm{l}$ by addition of nuclease-free $\mathrm{H}_{2} \mathrm{O}_{\mathrm{dd}}$ (T143, Carl Roth). Samples were incubated for $60 \mathrm{~min}$ at $37^{\circ} \mathrm{C}$ and $2 \mathrm{~min}$ at $95^{\circ} \mathrm{C}$. Reverse transcription was performed for all samples at the same time to minimize experimental variation.

\section{Quantitative real-time polymerase chain reaction}

Quantitative real-time polymerase chain reaction (RTqPCR) was performed according to MIQE guidelines $[17,30]$. For RT-qPCR the Mastercycler ${ }^{\circledR}$ ep realplex-S thermocycler (Eppendorf AG, Hamburg, Germany) was used in combination with 96-well PCR plates (TW-MT, 712282, Biozym Scientific GmbH, Hessisch Oldendorf, Germany) and BZO cover sheeting (712350, Biozym Scientific $\mathrm{GmbH}$ ). Mastermix contained 7.5 $\mu \mathrm{l} \mathrm{SYBR}{ }^{\circledR}$ Green JumpStart $^{\mathrm{TM}}$ Taq ReadyMix ${ }^{\mathrm{TM}}$ (S4438, Sigma-Aldrich, Munich, Germany), $0.75 \mu$ of each primer in a total amount of $13.5 \mu \mathrm{l}$ by addition of nuclease-free $\mathrm{H}_{2} \mathrm{O}_{\mathrm{dd}}$ (T143, Carl Roth, Karlsruhe, Germany) for each sample. Finally $1.5 \mu \mathrm{l}$ cDNA in duplet per sample was added to the mastermix. RTqPCR was performed in 45 cycles (initial: $5 \mathrm{~min}$ at $95^{\circ} \mathrm{C}$, each cycle: $10 \mathrm{~s}$ at $95^{\circ} \mathrm{C}, 8 \mathrm{~s}$ at $60^{\circ} \mathrm{C}, 8 \mathrm{~s}$ at $72^{\circ} \mathrm{C}$ ). At the end of each extension step SYBR ${ }^{\circledR}$ Green I fluorescence was measured at $521 \mathrm{~nm}$. For calculation of relative gene expression, we used a set of two reference genes (TBP and $P P I B)$, which have been shown to be stably expressed in PDLF under the conditions investigated [30]. Relative gene expression was calculated as $2^{-\Delta \mathrm{Cq}}$ with $\Delta \mathrm{Cq}=\mathrm{Cq}$ (target gene)- $\mathrm{Cq}$ (geometric mean TBP/PPIB) [21]. All primers (Eurofins MWG, Huntsville, AL, USA) are listed in Table 1 and were constructed using NCBI PrimerBLAST according to MIQE guidelines as previously described [17, 19, 30]. For each primer pair and RT-qPCR run, a no-templatecontrol without cDNA was performed. Experiments were repeated two to three times $(N=2-3)$ with at least two to three biological replicates $(n=2-3)$.

\section{Statistical methods}

One-way analysis of variance (ANOVA) followed by Games-Howell post hoc tests was performed using GraphPad Prism version 8.0.0 for Windows (GraphPad Software, San Diego, CA, USA). Welch tests were performed in case of heterogeneity of variance. The significance level was set at $p \leq 0.05$.

\section{Results}

\section{Impact of tensile strain and sodium chloride on cell number and cytotoxicity}

First, we assessed the PDLF number and possible cytotoxic effects after $48 \mathrm{~h}$ of tensile strain and $72 \mathrm{~h}$ of sodium chloride treatment. Tensile strain significantly increased cell numbers under normal salt treatment (NS, $p=0.035)$, while high salt treatment (HS; $p=0.036$ ) with an additional $40 \mathrm{mM} \mathrm{NaCl}$ in the medium had no effect on cell number (Fig. 1b). Neither tension treatment nor addition of $40 \mathrm{mM}$ $\mathrm{NaCl}$ showed any cytotoxic effects as no significantly increased LDH activity could be detected $(p=0.889)$ in the cell culture supernatant throughout the tested conditions (Fig. 1c).

\section{Effects of tensile strain and sodium chloride on extracellular-matrix-forming genes}

Next, we investigated expression of genes involved in remodeling and formation of the extracellular matrix (prolyl4-hydroxylase-1 [P4HA1], collagen-1- $\alpha-2$ [COL1A2], fibronectin1 [FN1], and matrix-metalloproteinase-8 [MMP8]). Neither tensile strain nor salt treatment showed significant effects on the gene expression of P4HAl $(p=0.553$, Fig. 2a). In contrast, gene expression of COL1A2 ( $p=0.038$, Fig. 2b) and FN1 was significantly elevated under HS conditions ( $p=0.024$, Fig. $2 \mathrm{c}$ ) without additional tensile strain. Tension had no significant effect on COLIA2 or FN1 gene expression under NS conditions (COL1A2: $p=0.120$, FN1: $p=0.173)$ or under high salt conditions (COL1A2: $p=0.998, F N 1: p=0.780$ ). Gene expression of MMP8 was elevated after addition of $40 \mathrm{mM} \mathrm{NaCl}$ without $(p=0.004)$ and with stretching $(p<0.001)$ of PDLF (Fig. 2d). Tensile strain itself had no significant effect on MMP8 gene expression levels (NS: $p=0.904$, HS: $p=0.769$ ).

\section{Effects of tensile strain and sodium chloride on angiogenetic and bone-forming genes}

The vascular endothelial growth factor A (VEGFA) is involved in tissue neoformation and responsible for growth of blood vessels. Surprisingly, neither tensile strain (NS: $p=0.170$, HS: $p=0.262$ ) nor addition of $\mathrm{NaCl}$ (without tension: $p=0.972$, tension: $p=0.979$ ) showed a significant effect on gene expression of VEGFA (Fig. 3a), although an increase of VEGFA gene expression under tensile strain was observed by tendency. The alkaline phosphatase ( $A L P)$ gene is involved in bone formation. We observed a significant increase in $A L P$ gene expression after tensile strain under NS conditions ( $p=0.002$, Fig. $3 b$ ). Treatment of PDLF with $40 \mathrm{mM} \mathrm{NaCl}$ also increased $A L P$ gene expression sig- 
Fig. 2 Changes in expression of the extracellular-matrix-reorganizing genes P4HAl (a), COL1A2 (b), FN1 (c), and $M M P 8$ (d). NS normal salt conditions, $H S$ high salt conditions, $A U$ arbitrary units, error bars error of the mean. Statistics: Analysis of variance (ANOVA) using the Games-Howell post hoc test: $* p \leq 0.05, * * p \leq 0.01$, $* * * p \leq 0.001$

Abb. 2 Veränderungen in der Expression der extrazellulären-Matrix-reorganisierenden Gene P4HA1 (a), COL1A2 (b), FN1 (c) und MMP8 (d). (NS Normalsalzbedingungen, $H S$ Hochsalzbedingungen, $A U$ arbiträre Einheiten, Fehlerbalken Fehler des Mittelwerts. Statistik: ANOVA (,,analysis of variance") mit Games-Howell-Post-hoc-Test: $* p \leq 0,05$, $* * p \leq 0,01, * * * p \leq 0,001)$
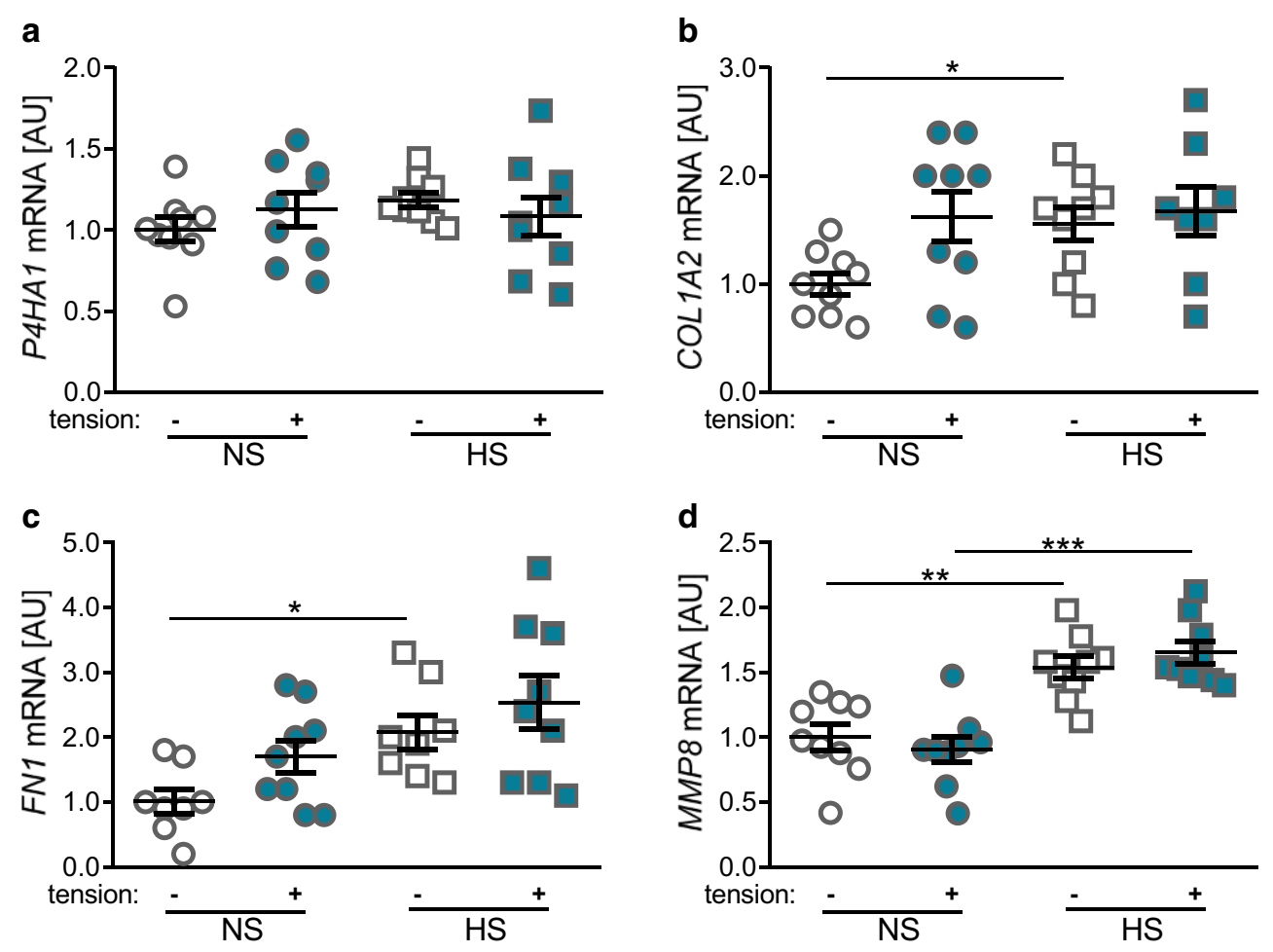
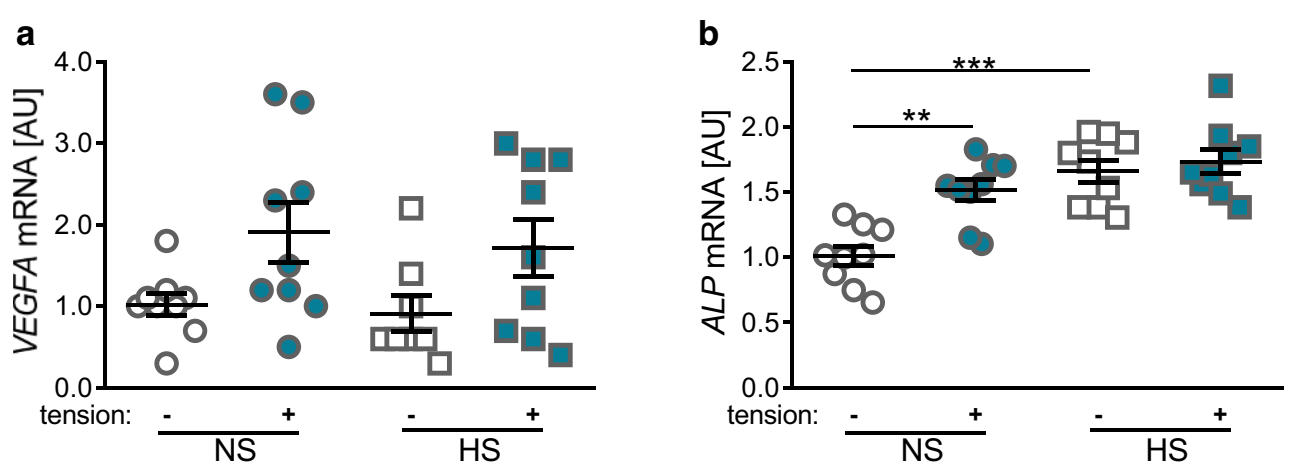

Fig. 3 Changes in expression of the angiogenesis-inducing gene VEGFA (a) and the osteoblastogenesis-inducing gene ALP (b). NS normal salt conditions, $H S$ high salt conditions, $A U$ arbitrary units, error bars error of the mean. Statistics: Analysis of variance (ANOVA) using the Games-Howell post hoc test: $* * p \leq 0.01$, $* * * p \leq 0.001$

Abb. 3 Veränderungen in der Expression des Angiogenese-induzierenden Gens VEGFA (a) und des Osteoblastogenese-induzierenden Gens $A L P$ (b). (NS Normalsalzbedingungen, HS Hochsalzbedingungen, AU arbiträre Einheiten, Fehlerbalken Fehler des Mittelwerts. Statistik: ANOVA (,analysis of variance“) mit Games-Howell-Post-hoc-Test: $* * p \leq 0,01, * * * p \leq 0,001$ )

nificantly $(p<0.001)$. However, we no longer detected an increased $A L P$ gene expression due to tensile strain under HS conditions ( $p=0.312$, Fig. $3 b)$.

\section{Effects of tensile strain and HS on proinflammatory genes}

Next we focused on the gene expression of proinflammatory genes like cyclooxygenase $2(\mathrm{COX}-2)$ and interleukin $6(I L-6)$. Tensile strain resulted in a significant increase of COX-2 gene expression $(p=0.017$, Fig. 4a), whereas $I L-6$ gene expression was significantly reduced ( $p=0.019$, Fig. $4 \mathrm{~b})$ under NS conditions. Salt treatment enhanced $C O X-2$ gene expression $(p<0.001$, Fig. $4 a)$ and also reduced $I L-6$ gene expression $(p=0.031$, Fig. 4 b) compared to NS conditions.

\section{Effects of cell stretching and salt treatment on the RANKL/OPG ratio}

The $R A N K L / O P G$ ratio plays a major regulating role during bone resorption. Tensile strain reduced gene expression of 

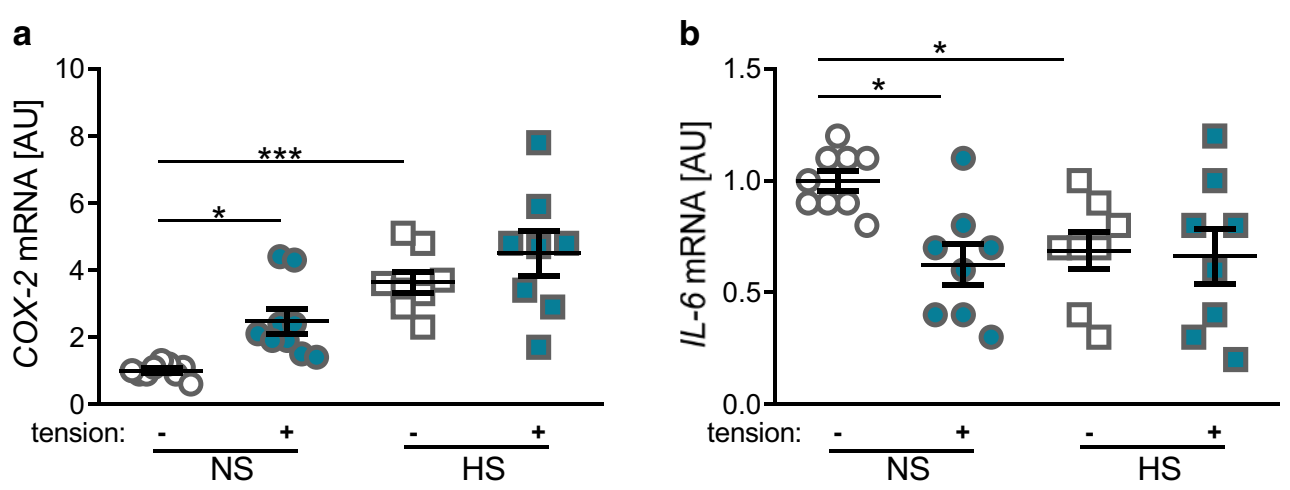

Fig. 4 Changes in expression of the proinflammatory genes COX-2 (a) and $I L-6$ (b). NS normal salt conditions, $H S$ high salt conditions, $A U$ arbitrary units, error bars error of the mean. Statistics: Analysis of variance (ANOVA) using the Games-Howell post hoc test: $* p \leq 0.05$, $* * * p \leq 0.001$ Abb. 4 Veränderungen in der Expression der proinflammatorischen Gene COX-2 (a) und IL-6 (b). (NS Normalsalzbedingungen, HS Hochsalzbedingungen, $A U$ arbiträre Einheiten, Fehlerbalken Fehler des Mittelwerts. Statistik: ANOVA (,analysis of variance“) mit Games-HowellPost-hoc-Test: $* p \leq 0,05, * * * p \leq 0,001)$

RANKL significantly ( $p=0.008$, Fig. 5a), whereas $O P G$ gene expression was not affected by PDLF stretching $(p=0.355$, Fig. $5 b)$. This resulted in a significantly reduced $R A N K L / O P G$ ratio $(p=0.044$, Fig. $5 c)$ during tensile strain under NS conditions. HS conditions increased RANKL gene expression without $(p=0.023)$ and with additional tensile strain $(p<0.001) . O P G$ gene expression was also increased under HS conditions without tensile strain $(p=0.042$, Fig. 5b), whereas $O P G$ expression was not affected under HS conditions with tension treatment $(p=0.815)$. This led to a significantly increased $R A N K L / O P G$ ratio under HS conditions during tensile strain compared to NS conditions with cell stretching ( $p=0.033$, Fig. $5 c)$.

\section{Discussion}

In this study, we investigated the effects of tensile strain and salt (sodium chloride) on the expression levels of genes involved in extracellular matrix reorganization, angiogenesis, bone remodeling, and inflammation in PDLF. We could show that application of tension resulted in a reduced $R A N K L / O P G$ ratio, which was accompanied by enhanced $A L P$ gene expression indicating elevated bone formation. Tensile strain increased $C O X-2$, but concurrently reduced $I L-6$ gene expression. Surprisingly, we detected no effects of tension on genes involved in extracellular matrix remodeling or angiogenesis, whereas salt had a significant impact.

During orthodontic tooth movement, PDLF are suspected to be involved in extracellular matrix remodeling especially in the formation and breakdown of collagen fibrils [25]. For that reason, we analyzed expression of genes a

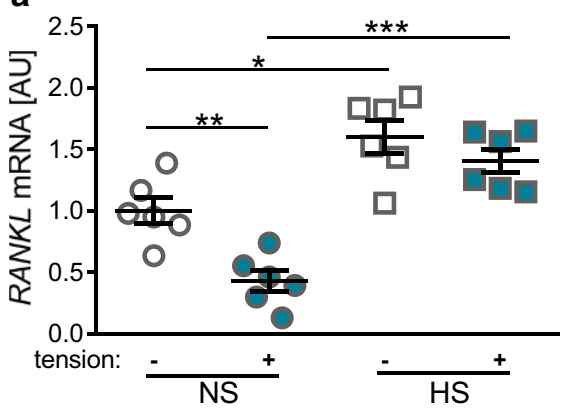

b

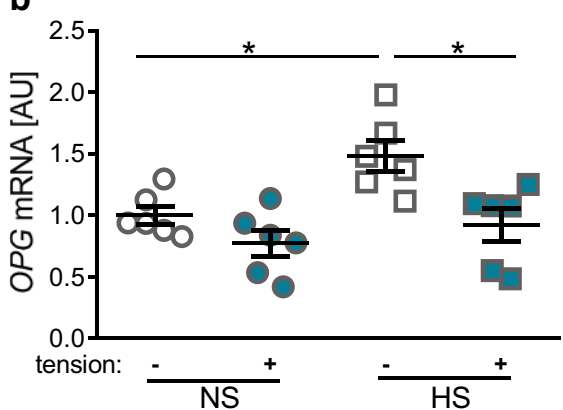

C

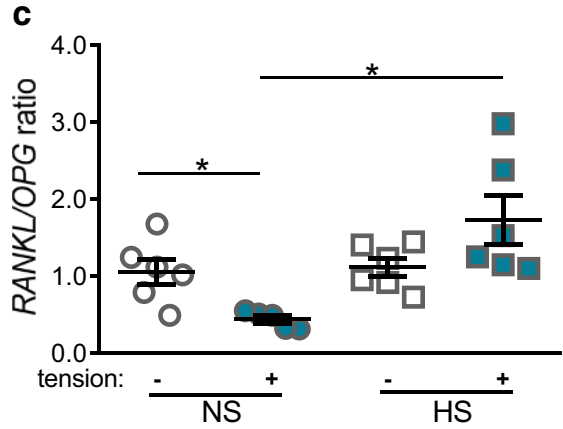

Fig. 5 Changes in expression of the bone remodeling genes $R A N K L(\mathbf{a})$ and $O P G(\mathbf{b})$ as well as $R A N K L / O P G$ ratio (c). $N S$ normal salt conditions, $H S$ high salt conditions, $A U$ arbitrary units, error bars error of the mean. Statistics: Analysis of variance (ANOVA) using the Games-Howell post hoc test: $* p \leq 0.05, * * p \leq 0.01, * * * p \leq 0.001$

Abb. 5 Veränderungen der Expression der am Knochenumbau beteiligten Gene RANKL (a) und $O P G(\mathbf{b})$ sowie des $R A N K L / O P G$-Verhältnisses (c). (NS Normalsalzbedingungen, $H S$ Hochsalzbedingungen, $A U$ arbiträre Einheiten, Fehlerbalken Fehler des Mittelwerts. Statistik: ANOVA (,,analysis of variance“) mit Games-Howell-Post-hoc-Test: *p $\leq 0,05, * * p \leq 0,01, * * * p \leq 0,001$ ) 
involved in collagen formation (COL1A2, P4HA1) and degradation (MMP8), but also fibronectin 1 (FN1), which interacts with collagen and other molecules of the extracellular matrix like heparin sulfate and serves as an adhesion molecule [36]. Furthermore, FN1 has already been associated before with extracellular matrix remodeling during orthodontic tooth movement [1]. We detected no changes in expression of genes involved in collagen synthesis after application of tension. Howard et al. reported increased FN1 expression after $10 \%$ cyclic tensile strain; however, COL1 expression was not changed by PDLF stretching [11], supporting our data. A recent study investigated collagen and fibronectin expression in histological samples. They observed a downregulation of FN1, while COL1 was upregulated at the tension side [26]. Compressive force treatment was reported to affect collagen formation within $24 \mathrm{~h}$ because of increased gene expression of COL1A2 and P4HA1 [38]. In contrast to genes involved in collagen formation, FN1 was not affected by compressive force treatment [38]. MMPs are proteolytic enzymes, which degenerate different components of the extracellular matrix [4]. In this study we investigated the gene expression of $M M P 8$, which acts as collagenase and is expressed by PDLF [46]. Contrary to our results it was reported that collagenases like MMP8 were upregulated by tensile forces with the strength of the tensile strain playing a crucial role [5, 13, 31], whereas MMP8 was downregulated after compressive force treatment in PDLF [39, 43]. In the current study, salt (sodium chloride) treatment affected gene expression of COL1A2, FN1 and MMP8 in PDLF, as reported previously [39]. Salt consumption has already been reported to be involved in extracellular matrix reorganization, as it impacts on glycosaminoglycan sulfatation [45, 49].

Application of orthodontic forces changes the blood flow in the surrounding tissue. To avoid hypoxic conditions, vascular endothelial growth factor A (VEGFA) expression is induced in the periodontal ligament (PDL) due to mechanical strain. VEGFA is a growth factor involved in the reshaping of blood vessels and angiogenesis [7]. Increased VEGFA expression was reported at compression and tension areas of the PDL in histological samples after tooth movement [27]. In this study, however, we detected no significant effect of tensile strain or salt on VEGFA gene expression. As increased VEGFA gene expression, however, occurred quite early after the onset of mechanical strain [38], our timing of detection might have been too late, as we analyzed VEGFA gene expression not earlier than after $48 \mathrm{~h}$ of tensile strain.

According to the common pressure-tension theory during orthodontic tooth movement, bone resorption happens at the pressure areas, while bone formation occurs at tension areas of the PDL [25]. Alkaline phosphatase (ALP) activity is elevated in the periodontal ligament compared to other connective tissues and is associated with bone formation [10]. In line with our data, static and cyclic tensile strain increased ALP expression dependent on the applied magnitude of tensile strain [12, 30, 31, 50], which may enhance the osteoblastic phenotype of PDLF and prompt bone formation $[12,55]$. Furthermore, increased ALP levels were observed in human crevicular fluid after orthodontic treatment [15, 24, 35]. Salt treatment enhanced ALP gene expression, suggesting that $\mathrm{NaCl}$ promotes an osteoblastic phenotype of PDLF.

PDLF modulate the expression of proinflammatory genes in reaction to orthodontic forces [16, 30, 38]. In this study gene expression of $C O X-2$ was increased after $48 \mathrm{~h}$ of tensile strain. This was in line with Shimizu et al. who reported that enhanced COX-2 expression was accompanied by increased PG-E2 levels in PDLF after stimulation with cyclic stretching [40]. As already reported, salt treatment of PDLF also enhanced $C O X-2$ gene expression [39]. As it is well established that $\mathrm{NaCl}$ increases expression of the osmoprotective transcription factor NFAT5 [23, 33] and that COX-2 is an NFAT5 target gene [9], this is not by surprise. In contrast to $C O X-2$, gene expression of $I L-6$ was reduced with tension treatment and $\mathrm{NaCl}$ addition. This is in line with prior publications reporting simultaneous increase of COX-2 and reduction of $I L-6$ expression upon tensile strain [30, 39]. IL-6 modulates the extent of immune responses during inflammation [34] and can influence osteoclastogenesis [20]. Reduction of $I L-6$ expression after stretching and $\mathrm{NaCl}$ could contribute to the osteoblastic phenotype of PDLF.

Bone metabolism strongly depends on the interaction of RANKL (receptor activator of NF- $\kappa$ B ligand) and OPG (osteoprotegerin) [47]. While binding of RANKL to the RANK receptor on osteoclast precursor cells is critical for osteoclast formation and activation, secretion of the decoy receptor OPG inhibits this interaction [47]. In contrast to pressure application [38, 39], tensile strain resulted in reduced $R A N K L$ expression, while $O P G$ gene expression remained unaffected. This resulted in a shifting of the $R A N K L / O P G$ ratio towards $O P G$ suggesting less bone resorption. As already reported, salt treatment increased gene expression of RANKL and $O P G$ in PDLF without tensile strain [39]. In contrast to the normal salt-treated PDLFs, we observed a reduction of $O P G$ gene expression under high salt treatment with additional tensile strain, resulting in an increased $R A N K L / O P G$ ratio upon salt treatment with stretching. Therefore salt, that is sodium chloride, may modulate bone metabolism at the tension site as well.

For our in vitro experiments, we used salt concentrations $(40 \mathrm{mM})$ corresponding to the local $\mathrm{Na}^{+}$accumulation measured under high salt diet in the murine mandible including the associated mucosa [39] to maximize transferability of results to the in vivo situation within the PDL and surround- 
ing alveolar bone. The addition of $40 \mathrm{mM} \mathrm{NaCl}$ to the cell culture medium did have an impact on the expression of genes involved in extracellular matrix and bone remodeling as well as prostaglandin synthesis supporting previous results [39]. A high salt environment in combination with force application affected the RANKL/OPG ratio under tensile strain as well as during compressive force treatment, indicating a stimulating role of salt on osteoclastogenesis and thereby bone resorption [39]. To further investigate the role of salt on orthodontic tooth movement, in vivo experiments with animals receiving low, normal, and high salt diets with and without orthodontic tooth movement are required. Based on our in vitro results, we surmise that increased sodium concentrations due to high salt intake or possibly a local therapeutic injection into the periodontal ligament may accelerate orthodontic tooth movement due to an increase in osteoclastogenesis in pressure areas as well as elevated osteoblastic activity in tensile areas, but this might also have detrimental effects such as periodontal bone loss or dental root resorptions, which needs to be clarified in further in vivo studies.

\section{Conclusions}

- Salt $(\mathrm{NaCl})$ treatment has an impact on extracellular matrix formation, expression of proinflammatory cytokines and bone metabolism during tensile strain in PDLF (periodontal ligament fibroblasts).

- Additional $\mathrm{NaCl}$ exposure increased $A L P$ (alkaline phosphatase) expression by PDLF and could thereby promote bone formation at tension areas of the PDL (periodontal ligament).

- Excessive salt intake during orthodontic therapy may cause stimulatory effects on periodontal inflammation and bone resorption, possibly leading to increased tooth movement, but also periodontal bone loss and dental root resorptions.

- Tensile strain did not affect expression of genes involved in angiogenesis or extracellular matrix reorganization in PDLFs.

- PDLFs modulate inflammatory responses and bone remodeling in reaction to static tensile strain.

Acknowledgements The authors wish to thank Ms. Zaglauer for her technical support. The authors want to thank the German Orthodontic Society (DGKFO, Kirschneck 2018) for their support and the German Research Foundation DFG (SCHR 1622/1-1 and KI 2105/2-1) for funding of this study.

Funding This study was funded by the German Research Foundation DFG (SCHR 1622/1-1 and KI 2105/2-1).

Funding Open Access funding enabled and organized by Projekt DEAL.

\section{Compliance with ethical guidelines}

Conflict of interest A. Schröder, J. Gubernator, U. Nazet, G. Spanier, J. Jantsch, P. Proff and C. Kirschneck report no financial or other conflict of interest relevant to this article, which is the intellectual property of the authors.

Ethical standards All procedures performed in studies involving human participants were in accordance with the ethical standards of the institutional and/or national research committee and with the 1964 Helsinki declaration and its later amendments or comparable ethical standards. Approval for the collection and usage of periodontal ligament fibroblasts was obtained from the ethics committee of the University of Regensburg, Germany (approval number 12-170-0150). This article does not contain any studies with animals.

Open Access This article is licensed under a Creative Commons Attribution 4.0 International License, which permits use, sharing, adaptation, distribution and reproduction in any medium or format, as long as you give appropriate credit to the original author(s) and the source, provide a link to the Creative Commons licence, and indicate if changes were made. The images or other third party material in this article are included in the article's Creative Commons licence, unless indicated otherwise in a credit line to the material. If material is not included in the article's Creative Commons licence and your intended use is not permitted by statutory regulation or exceeds the permitted use, you will need to obtain permission directly from the copyright holder. To view a copy of this licence, visit http://creativecommons.org/licenses/by/4. $0 /$.

\section{References}

1. Anastasi G, Cordasco G, Matarese G et al (2008) An immunohistochemical, histological, and electron-microscopic study of the human periodontal ligament during orthodontic treatment. Int $\mathrm{J}$ Mol Med 21:545-554

2. Bernhardt O, Krey K-F, Daboul A et al (2019) New insights in the link between malocclusion and periodontal disease. J Clin Periodontol 46:144-159

3. Binger KJ, Gebhardt M, Heinig M et al (2015) High salt reduces the activation of IL-4- and IL-13-stimulated macrophages. J Clin Invest 125:4223-4238

4. Birkedal-Hansen H, Moore WG, Bodden MK et al (1993) Matrix metalloproteinases: a review. Crit Rev Oral Biol Med 4:197-250

5. Bolcato-Bellemin AL, Elkaim R, Abehsera A et al (2000) Expression of mRNAs encoding for alpha and beta integrin subunits, MMPs, and TIMPs in stretched human periodontal ligament and gingival fibroblasts. J Dent Res 79:1712-1716

6. Deutsche Gesellschaft für Ernährung e.V. (DGE) (2017) https:// www.dge.de/presse/pm/dge-aktualisiert-die-referenzwerte-fuernatrium-chlorid-und-kalium/

7. Di Domenico M, D'apuzzo F, Feola A et al (2012) Cytokines and VEGF induction in orthodontic movement in animal models. J Biomed Biotechnol 2012:201689

8. Dutra SR, Pretti H, Martins MT et al (2018) Impact of malocclusion on the quality of life of children aged 8 to 10 years. Dental Press J Orthod 23:46-53

9. Favale NO, Casali CI, Lepera LG et al (2009) Hypertonic induction of COX2 expression requires TonEBP/NFAT5 in renal epithelial cells. Biochem Biophys Res Commun 381:301-305

10. Grundt A, Grafe IA, Liegibel U et al (2009) Direct effects of osteoprotegerin on human bone cell metabolism. Biochem Biophys Res Commun 389:550-555 
11. Howard PS, Kucich U, Taliwal R et al (1998) Mechanical forces alter extracellular matrix synthesis by human periodontal ligament fibroblasts. J Periodontal Res 33:500-508

12. Jacobs C, Grimm S, Ziebart T et al (2013) Osteogenic differentiation of periodontal fibroblasts is dependent on the strength of mechanical strain. Arch Oral Biol 58:896-904

13. Jacobs C, Walter C, Ziebart $T$ et al (2014) Induction of IL-6 and MMP-8 in human periodontal fibroblasts by static tensile strain. Clin Oral Investig 18:901-908

14. Jantsch J, Schatz V, Friedrich D et al (2015) Cutaneous Na+ storage strengthens the antimicrobial barrier function of the skin and boosts macrophage-driven host defense. Cell Metab 21:493-501

15. Jeyraj Y, Katta AK, Vannala V et al (2015) Estimation of alkaline phosphatase in the gingival crevicular fluid during orthodontic tooth movement in premolar extraction cases to predict therapeutic progression. J Nat Sci Biol Med 6:343-346

16. Kanzaki H, Chiba M, Shimizu Y et al (2002) Periodontal ligament cells under mechanical stress induce osteoclastogenesis by receptor activator of nuclear factor kappaB ligand up-regulation via prostaglandin E2 synthesis. J Bone Miner Res 17:210-220

17. Kirschneck C, Batschkus S, Proff P et al (2017) Valid gene expression normalization by RT-qPCR in studies on hPDL fibroblasts with focus on orthodontic tooth movement and periodontitis. Sci Rep $7: 14751$

18. Kirschneck C, Maurer M, Wolf M et al (2017) Regular nicotine intake increased tooth movement velocity, osteoclastogenesis and orthodontically induced dental root resorptions in a rat model. Int $\mathrm{J}$ Oral Sci 9:174-184

19. Kirschneck C, Proff P, Fanghänel J et al (2016) Reference genes for valid gene expression studies on rat dental, periodontal and alveolar bone tissue by means of RT-qPCR with a focus on orthodontic tooth movement and periodontitis. Ann Anat 204:93-105

20. Kurihara N, Bertolini D, Suda T et al (1990) IL-6 stimulates osteoclast-like multinucleated cell formation in long term human marrow cultures by inducing IL-1 release. J Immunol 144:4226-4230

21. Livak KJ, Schmittgen TD (2001) Analysis of relative gene expression data using real-time quantitative PCR and the 2(-Delta Delta C(T)) Method. Methods 25:402-408

22. Machnik A, Dahlmann A, Kopp C et al (2010) Mononuclear phagocyte system depletion blocks interstitial tonicity-responsive enhancer binding protein/vascular endothelial growth factor $\mathrm{C}$ expression and induces salt-sensitive hypertension in rats. Hypertension 55:755-761

23. Machnik A, Neuhofer W, Jantsch J et al (2009) Macrophages regulate salt-dependent volume and blood pressure by a vascular endothelial growth factor-C-dependent buffering mechanism. Nat Med 15:545-552

24. Megat Abdul Wahab R, Md Dasor M, Senafi S et al (2013) Crevicular alkaline phosphatase activity and rate of tooth movement of female orthodontic subjects under different continuous force applications. Int J Dent 2013:245818

25. Meikle MC (2006) The tissue, cellular, and molecular regulation of orthodontic tooth movement: 100 years after Carl Sandstedt. Eur J Orthod 28:221-240

26. Militi A, Cutroneo G, Favaloro A et al (2019) An immunofluorescence study on VEGF and extracellular matrix proteins in human periodontal ligament during tooth movement. Heliyon 5:e2572

27. Miyagawa A, Chiba M, Hayashi H et al (2009) Compressive force induces VEGF production in periodontal tissues. J Dent Res 88:752-756

28. Müller DN, Wilck N, Haase S et al (2019) Sodium in the microenvironment regulates immune responses and tissue homeostasis. Nat Rev Immunol 19:243-254

29. Muluke M, Gold T, Kiefhaber K et al (2016) Diet-induced obesity and its differential impact on periodontal bone loss. J Dent Res 95:223-229
30. Nazet U, Schröder A, Spanier G et al (2019) Simplified method for applying static isotropic tensile strain in cell culture experiments with identification of valid RT-qPCR reference genes for PDL fibroblasts. Eur J Orthod. https://doi.org/10.1093/ejo/cjz052

31. Nettelhoff L, Grimm S, Jacobs C et al (2016) Influence of mechanical compression on human periodontal ligament fibroblasts and osteoblasts. Clin Oral Investig 20(3):621-629

32. Neubert P, Weichselbaum A, Reitinger C et al (2019) HIF1A and NFAT5 coordinate Na+-boosted antibacterial defense via enhanced autophagy and autolysosomal targeting. Autophagy 15:1899-1916

33. Neuhofer W, Woo SK, Na KY et al (2002) Regulation of TonEBP transcriptional activator in MDCK cells following changes in ambient tonicity. Am J Physiol Cell Physiol 283:C1604-C1611

34. Okada N, Kobayashi M, Mugikura K et al (1997) Interleukin-6 production in human fibroblasts derived from periodontal tissues is differentially regulated by cytokines and a glucocorticoid. J Periodont Res 32:559-569

35. Perinetti G, Paolantonio M, D'Attilio M et al (2002) Alkaline phosphatase activity in gingival crevicular fluid during human orthodontic tooth movement. Am J Orthod Dentofacial Orthop 122:548-556

36. Romberger DJ (1997) Fibronectin. Int J Biochem Cell Biol 29:939-943

37. Sá-Pinto AC, Rego TM, Marques LS et al (2018) Association between malocclusion and dental caries in adolescents: a systematic review and meta-analysis. Eur Arch Paediatr Dent 19:73-82

38. Schröder A, Bauer K, Spanier G et al (2018) Expression kinetics of human periodontal ligament fibroblasts in the early phases of orthodontic tooth movement (Expression kinetics of human periodontal ligament fibroblasts in the early phases of orthodontic tooth movement). J Orofac Orthop 79:337-351. https://doi.org/10.1007/ s00056-018-0145-1

39. Schröder A, Nazet U, Neubert P et al (2019) Sodium-chloride-induced effects on the expression profile of human periodontal ligament fibroblasts with focus on simulated orthodontic tooth movement. Eur J Oral Sci 127:386-395

40. Shimizu N, Ozawa Y, Yamaguchi M et al (1998) Induction of COX-2 expression by mechanical tension force in human periodontal ligament cells. J Periodontol 69:670-677

41. Staufer K, Landmesser H (2004) Effects of crowding in the lower anterior segment - a risk evaluation depending upon the degree of crowding. J Orofac Orthop 65:13-25

42. Taibah SM, Al-Hummayani FM (2017) Effect of malocclusion on the self-esteem of adolescents. J Orthod Sci 6:123-128

43. Takahashi I, Nishimura M, Onodera K et al (2003) Expression of MMP-8 and MMP-13 genes in the periodontal ligament during tooth movement in rats. J Dent Res 82:646-651

44. Titze J, Rittweger J, Dietsch P et al (2004) Hypertension, sodium retention, calcium excretion and osteopenia in Dahl rats. J Hypertens 22:803-810

45. Titze J, Shakibaei M, Schafflhuber M et al (2004) Glycosaminoglycan polymerization may enable osmotically inactive $\mathrm{Na}+$ storage in the skin. Am J Physiol Heart Circ Physiol 287:H203-H208

46. Tsubota M, Sasano Y, Takahashi I et al (2002) Expression of MMP-8 and MMP-13 mRNAs in rat periodontium during tooth eruption. J Dent Res 81:673-678

47. Tyrovola JB, Spyropoulos MN, Makou M et al (2008) Root resorption and the OPG/RANKL/RANK system: a mini review. J Oral Sci 50:367-376

48. Ullrich N, Schröder A, Jantsch J et al (2019) The role of mechanotransduction versus hypoxia during simulated orthodontic compressive strain-an in vitro study of human periodontal ligament fibroblasts. Int J Oral Sci 11:33

49. Volpi N, Maccari F, Titze J (2005) Simultaneous detection of submicrogram quantities of hyaluronic acid and dermatan sulfate on agarose-gel by sequential staining with toluidine blue and StainsAll. J Chromatogr B Analyt Technol Biomed Life Sci 820:131-135 
50. Wescott DC, Pinkerton MN, Gaffey BJ et al (2007) Osteogenic gene expression by human periodontal ligament cells under cyclic tension. J Dent Res 86:1212-1216

51. WHO (2012) WHO guideling: sodium intake for adults and children. ISBN: 9789241504836

52. Woelber JP, Bremer K, Vach K et al (2016) An oral health optimized diet can reduce gingival and periodontal inflammation in humans - a randomized controlled pilot study. BMC Oral Health $17: 28$
53. Wolf M, Lossdörfer S, Römer P et al (2016) Short-term heat pretreatment modulates the release of HMGB1 and pro-inflammatory cytokines in hPDL cells following mechanical loading and affects monocyte behavior. Clin Oral Investig 20:923-931

54. Wu L, Luthringer BJC, Feyerabend F et al (2017) Increased levels of sodium chloride directly increase osteoclastic differentiation and resorption in mice and men. Osteoporos Int 28:3215-3228

55. Yu H-S, Kim J-J, Kim H-W et al (2016) Impact of mechanical stretch on the cell behaviors of bone and surrounding tissues. J Tissue Eng. https://doi.org/10.1177/2041731415618342 